\title{
Mid-Pliocene shifts in ocean overturning circulation and the onset of Quaternary-style climates
}

\author{
M. Sarnthein ${ }^{1,2, *}$, G. Bartoli ${ }^{1,3}$, M. Prange ${ }^{4}$, A. Schmittner ${ }^{5}$, B. Schneider ${ }^{1}$, M. Weinelt ${ }^{1}$, N. Andersen ${ }^{6}$, and \\ D. Garbe-Schönberg ${ }^{1}$ \\ ${ }^{1}$ Institute for Geosciences, University of Kiel, 24098 Kiel, Germany \\ ${ }^{2}$ Institute for Geology and Paleontology, University of Innsbruck, 6020, Innsbruck, Austria \\ ${ }^{3}$ Geologisches Institut, ETH Zuerich, 8092 Zurich, Switzerland \\ ${ }^{4}$ MARUM Center for Marine Environmental Sciences and Faculty of Geosciences, \\ University of Bremen, 28334 Bremen, Germany \\ ${ }^{5}$ College of Ocean and Atmospheric Sciences, Oregon State University, Corvallis OR 97331-5503, USA \\ ${ }^{6}$ Leibniz Laboratory, University of Kiel, 24098 Kiel, Germany \\ *Invited contribution by M. Sarnthein, recipient of the EGU Milutin Milankovic Medal 2006.
}

Received: 11 December 2008 - Published in Clim. Past Discuss.: 26 January 2009

Revised: 27 May 2009 - Accepted: 27 May 2009 - Published: 30 June 2009

\begin{abstract}
A major tipping point of Earth's history occurred during the mid-Pliocene: the onset of major Northern-Hemisphere Glaciation (NHG) and of pronounced, Quaternary-style cycles of glacial-to-interglacial climates, that contrast with more uniform climates over most of the preceding Cenozoic and continue until today (Zachos et al., 2001). The severe deterioration of climate occurred in three steps between 3.2 Ma (warm MIS K3) and $2.7 \mathrm{Ma}$ (glacial MIS G6/4) (Lisiecki and Raymo, 2005). Various models (sensu Driscoll and Haug, 1998) and paleoceanographic records (intercalibrated using orbital age control) suggest clear linkages between the onset of NHG and the three steps in the final closure of the Central American Seaways (CAS), deduced from rising salinity differences between Caribbean and the East Pacific. Each closing event led to an enhanced North Atlantic meridional overturning circulation and this strengthened the poleward transport of salt and heat (warmings of $+2-3^{\circ} \mathrm{C}$ ) (Bartoli et al., 2005). Also, the closing resulted in a slight rise in the poleward atmospheric moisture transport to northwestern Eurasia (Lunt et al., 2007), which probably led to an enhanced precipitation and fluvial runoff, lower sea surface salinity (SSS), and an increased seaice cover in the Arctic Ocean, hence promoting albedo and the build-up of continental ice sheets. Most important, new evidence shows that the closing of the CAS led to greater steric height of the North Pacific and thus doubled the low-
\end{abstract}

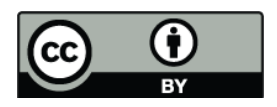

Correspondence to: M. Sarnthein (ms@gpi.uni-kiel.de) saline Arctic Throughflow from the Bering Strait to the East Greenland Current (EGC). Accordingly, Labrador Sea IODP Site 1307 displays an abrupt but irreversible EGC cooling of $6^{\circ} \mathrm{C}$ and freshening by $\sim 2$ psu from $3.25 / 3.16-3.00 \mathrm{Ma}$, right after the first but still reversible attempt of closing the CAS.

\section{Introduction - links to present concerns about future climate?}

At first glance, the mid-Pliocene onset of major Northern Hemisphere Glaciation and Quaternary-style climates, in particular the build-up of a continent-wide ice sheet on Greenland, seems to be a fairly academic question. However, this event may be linked to burning, unresolved questions on the Earth's uncertain future climate change.

A broad spectrum of model intercomparison data (Huybrechts et al., 2004) show that the present trend of global warming will induce both a modest increase in precipitation and an annual temperature rise by up to $8^{\circ} \mathrm{C}$ in Greenland over the 21 st century, two processes that counteract in their role for ice formation on Greenland. To test these opposing forces, Huybrechts et al. (op. cit.) ran a duplicate model experiment, using the ECHAM-4 and HadAM3 models (Fig. 1). Results from both experiments agree that the present greenhouse warming will lead to ice growth over most parts of Central Greenland (up to $2 \mathrm{~cm} / \mathrm{yr}$ ice gain), whereas large ice melt will occur along the West Greenland margin and in the far northeastern corner (up to $100 \mathrm{~cm} / \mathrm{yr}$ and more). In the models, the melting volume outweighs

Published by Copernicus Publications on behalf of the European Geosciences Union. 


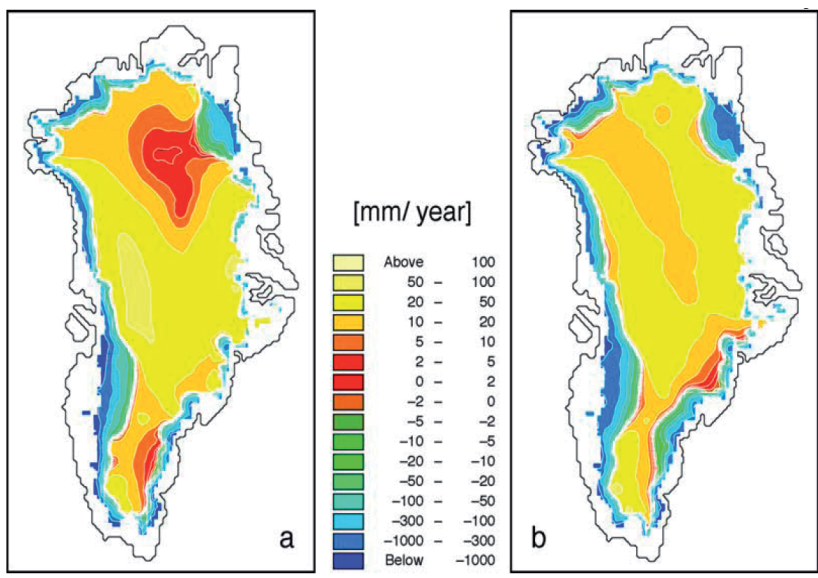

Fig. 1. Huybrechts' (2004) model of potential future variations in ice thickness on Greenland, modelled using the ECHAM4 (a) and HadAM3H (b) models.

growth and, therefore, a volume loss of Greenland ice is predicted for the 21st century. However, the magnitude of this melting is highly uncertain, ranging from an equivalent of 2 to $7 \mathrm{~cm}$ (in contrast to an overall gain of ice mass, predicted for Antarctica; Huybrechts et al., op. cit.). Likewise, modern elevation changes of the Greenland Ice Sheet derived from either satellite or aircraft altimetry are still controversial for altitudes of more than $2200 \mathrm{~m}$ (Hvidegaard and Sandberg, 2009; presented as EGU poster, 2009). In summary, these tests resulted in the burning question; how sensitive is the Greenland ice sheet to a warming climate? Alley et al. (2005) tried to answer the question and argued for the possibility of rapid and major ice loss and significant global sea level rise. Much of the answer may depend on the orders of magnitude of the competing poleward heat and the moisture transports reaching the northern North Atlantic and Eurasia.

It is the objective of this study to test a potential analogue case in the Late Neogene, the onset of Quaternary-style climates with the formation of Major Northern Hemisphere glaciation (NHG) approximately 3.0-2.7 Ma. This event is clearly revealed as a major tipping point in the long-term benthic oxygen isotope $\left(\delta^{18} \mathrm{O}\right)$ record of the Cenozoic ( $\mathrm{Za}-$ chos et al., 2001) and as a somewhat more gradual transition on top of some distinct steps of abrupt change in the millennial-scale resolution stacked benthic $\delta^{18} \mathrm{O}$ record LR04 of Lisiecki and Raymo (2005) (Fig. 2).

At the beginning of this paper, we shortly discuss the pros and cons of various hypotheses that try to explain the potential forcings controlling the onset of Major NHG in the mid-Pliocene. In this context, we stress the term "major", because minor, regional ice sheets in the Northern Hemisphere, particularly on Greenland, have already been registered since the Late Eocene (Eldrett et al., 2007) and in particular, since the Late Miocene as recently summarized in Paleoceanography (vol. 23/3) and by DeConto et al. (2008). However, a major rise in the discharge of ice rafted debris (IRD) to ambient seas suggests that full glaciation was only reached near 3.0-2.7 Ma, as first outlined by Shackleton et al. (1984) and displayed in further detail below. The main target of this paper is to summarize some recent lines of evidence (Bartoli et al., 2005, 2006; prelim. results of Groeneveld, 2005; Groeneveld et al., 2006; Schneider and Schmittner, 2006; Steph et al., 2006) that suggest direct links between the final closure of the Central American Seaways (CAS), more precisely that of Panama, and various follow-up processes in the North Atlantic, the atmosphere, and elsewhere, that may have triggered changes in poleward heat and moisture transports and finally, have been responsible for the onset of full glaciation on Greenland and for the numerous and gradually intensifying Quaternary-style glaciations in Eurasia and Laurentia.

\section{Conceptual models that try to explain the onset of ma- jor NHG}

Cane and Molnar (2001) first proposed the gradual closure of the Indonesian Seaways near $4 \mathrm{Ma}$ as forcing important to set the stage for the onset of Quaternary-style climates. More precisely, they suggested that the (poorly dated) northward plate-tectonic shift and the volcanic build-up of the (previously little known) small, elongated island of Halmahera northwest of New Guinea finally barred the West Pacific Warm Pool from warming the Indonesian Throughflow subsequently fed by cooler subsurface waters from the subtropical Northern Pacific (Fig. 3). On the other hand, the near-surface heat export from the West Pacific Warm Pool was then diverted to the northwestern Pacific. However, the Halmahera event occurred approximately one million years prior to the actual onset of the major NHG $(\sim 3.2-2.7 \mathrm{Ma})$ and thus cannot adequately explain this turning point in climate history.

Changes in orbital forcing of climate form a further potential mechanism to initiate the onset of major NHG, first proposed by Maslin et al. $(1995,1996)$ and recently by several authors such as Ravelo et al. (2006). Indeed, the amplitudes of orbital obliquity cycles increased significantly $\sim 3.0-2.5 \mathrm{Ma}$. This trend closely paralleled the major increase in global ice volume as recorded by the benthic $\delta^{18} \mathrm{O}$ signal (Fig. 2). However, the increase in amplitudes of obliquity cycles were reversible (at $2.25-1.8 \mathrm{Ma}$; Laskar et al., 2004) whereas the onset of major NHG was not or only to a minor degree and, thus, cannot be properly explained.

Huybers and Molnar (2007) established a more sophisticated approach to test the potential influence of orbital forcing on the onset of major NHG. They calculated the number of positive-degree days (PDD) for North America $>50^{\circ} \mathrm{N}$, obtained by applying temperature perturbations at high latitudes, expected to result from tropical anomalies and orbital variations (Fig. 4b). After $\sim 4.2 \mathrm{Ma}$ the PDD number decreased gradually down to a lowstand that persisted after 

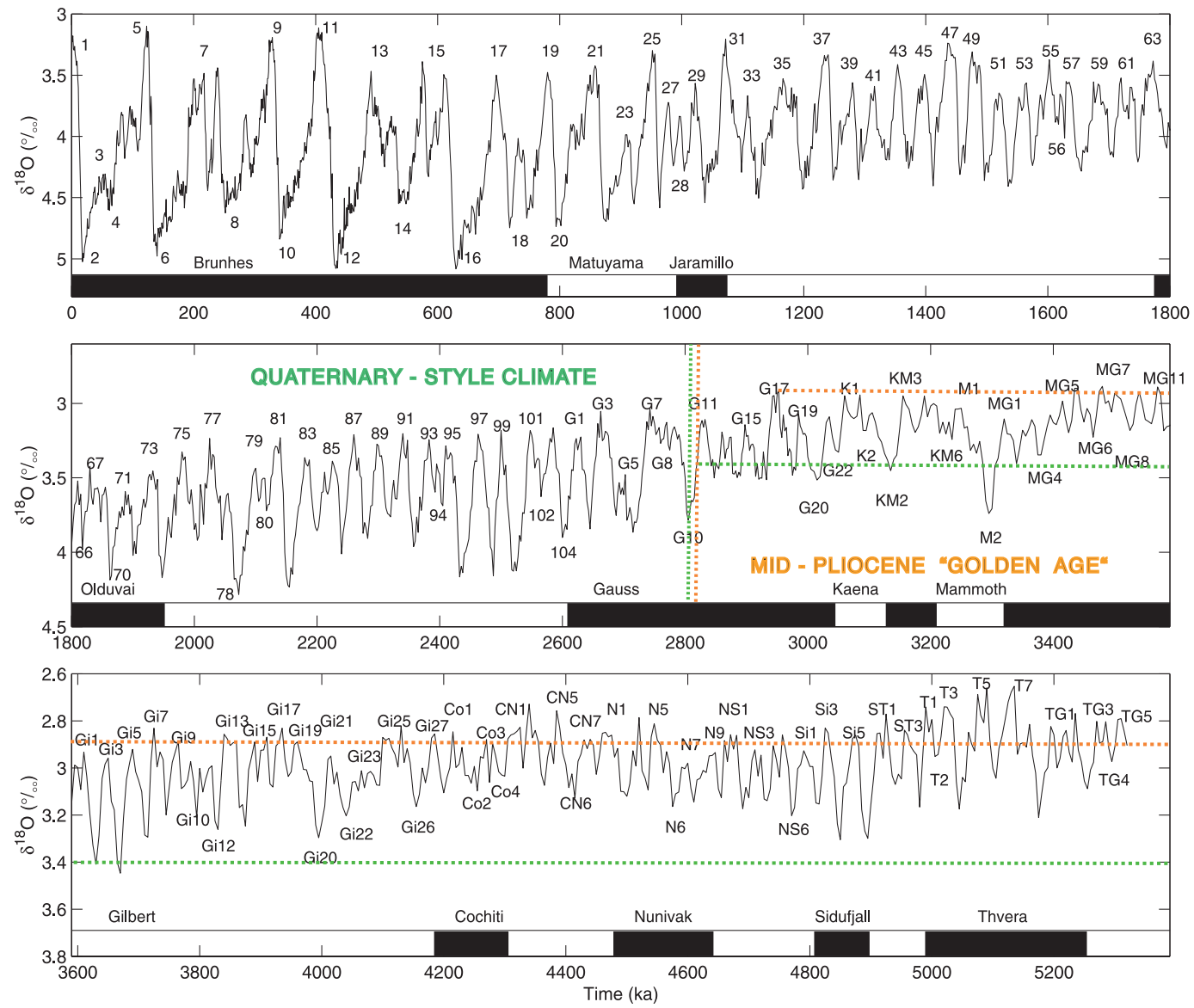

Fig. 2. "LR04" benthic $\delta^{18} \mathrm{O}$ record of global ice volume changes over the last 5 m.y. (Lisiecki and Raymo, 2005; modified): Transition from the mid-Pliocene "Golden Age" (2.9-3.4\%o) to Quaternary-style climates near 3.0-2.8 Ma. Note the expanded vertical scale at >3.6 Ma. The "Golden Age" represents a state of small-scale and fairly uniform climate oscillations that continued since $4.0 \mathrm{Ma}$, subsequent to a further $0.2-0.3 \%$ increase of cold $\delta^{18} \mathrm{O}$ excursions only near 4.2-4.0 Ma in the middle Early Pliocene. Numbers are marine isotope stages (MIS).

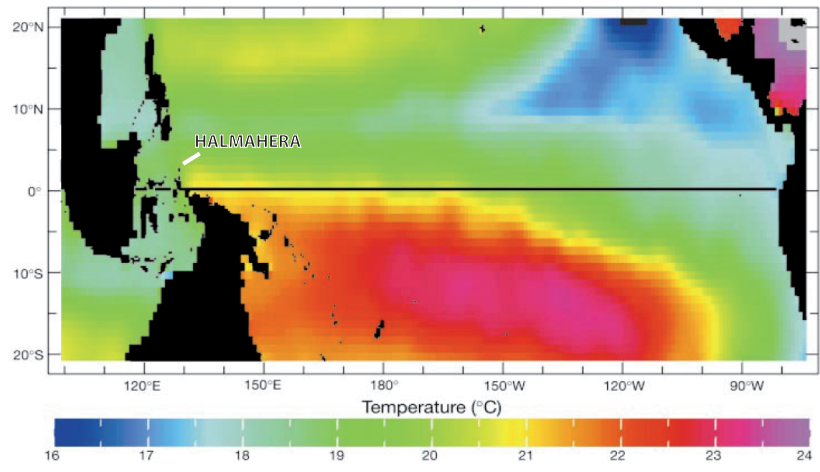

Fig. 3. Location of the island of Halmahera, today preventing the WPWP from flowing into the Indonesian Throughflow (Cane and Molnar, 2001; modified).

$\sim 1.8 \mathrm{Ma}$. This trend preceded the start of the long-term cooling of sea surface temperatures (SST) in the eastern equatorial Pacific (Lawrence et al., 2006) by $\sim 0.5 \mathrm{My}$ (Fig. 4a).
Likewise, it led the build-up of major NHG by more than $1 \mathrm{My}$ (Fig. 4c). This time span requires an extremely longlasting internal memory effect in the climate system, difficult to conceive, thus leading the authors to the honest conclusion: "Understanding the puzzle of what caused the eastern equatorial Pacific to cool off on a timescale too long to invoke the atmosphere-ocean-cryosphere system by itself now appears all the more pressing."

Recently, Lunt et al. (2008) made a strong argument that a decline in Pliocene atmospheric $\mathrm{CO}_{2}$ levels from 400 to $280 \mathrm{ppmv}$ may have controlled the onset of major NHG (Fig. 5). This decline won't affect precipitation patterns over Greenland and the ambient sea regions but will trigger a significant decrease of surface temperatures by $2-3^{\circ} \mathrm{C}$ all over Greenland, thus, triggering major ice growth - as to be expected from predicting a negative greenhouse effect.

The main problem of this model study is the sedimentary records published so far, which hardly show any evidence for an atmospheric $\mathrm{CO}_{2}$ drop as postulated for the mid-Pliocene. The two reconstructions cited (Kürschner et 

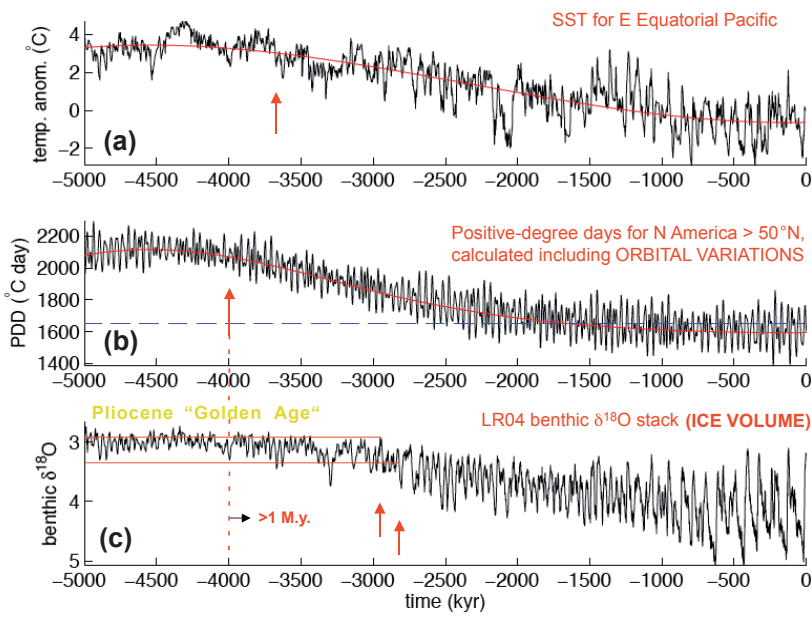

Fig. 4. Model of Huybers and Molnar (2007; suppl.) on (b) North America's "Positive Degree Days" (PDD), compared with East Pacific cooling/temperature anomalies (Lawrence et al., 2006) (a), and the $\delta^{18} \mathrm{O}$ record of growth of global ice volume (Lisiecki and Raymo, 2005) over the last 5 M.y (c). Vertical arrows mark major tipping points in climate records. The time span between the onset of reduced positive-degree days and the end of the Pliocene "Golden Age" amounts to > 1 M.y.

al., 1996; Raymo et al., 1996) do not display the postulated long-term shift in $\mathrm{CO}_{2}$ coeval with the onset of major NHG, moreover, they show a range of uncertainty of $\sim 120 \mathrm{ppmv}$, that is as large as the shift investigated, and finally, short-term trends that contradict each other. On the other hand, both alkenone- and boron-isotopes-based Cenozoic $\mathrm{CO}_{2}$ records established by Pagani et al. (2005) and Zachos et al. (2008) just revealed the contrary, no general $\mathrm{CO}_{2}$ decrease around $3 \mathrm{Ma}$ ago but a fairly constant "pre-industrial" $\mathrm{CO}_{2}$ level near 280-320 ppmv persisting over the last $25 \mathrm{My}$. Also, the cited records do not display a potential $400-\mathrm{ky}$ cycle in atmospheric $\mathrm{CO}_{2}$, which may be expected as implication of various planktic $\delta^{13} \mathrm{C}$ records of low-latitude ocean surface waters (Wang et al., 2004 and 2009) and may also play an important role in climate change, little recognized yet.

Finally and most important, in case we indeed identify sound evidence for the postulated unique and abrupt $\mathrm{CO}_{2}$ drop, the open question on the ultimate forcing for the onset of major NHG was just postponed one step further back. That is, we needed to solve the problem, which change in global carbon reservoirs, in particular which changes in ocean Meridional Overturning Circulation (MOC) may have triggered a fairly abrupt and long-lasting drop in atmospheric $\mathrm{CO}_{2}$ during the mid-Pliocene, then serving as a mere amplifier mechanism for climate change, similar to orbital-scale $\mathrm{CO}_{2}$ oscillations found over the last $400 \mathrm{ky}$ (Kawamura et al., 2007).

Possibly, the final closure of the CAS, which triggered major changes in the Atlantic MOC (see below), may

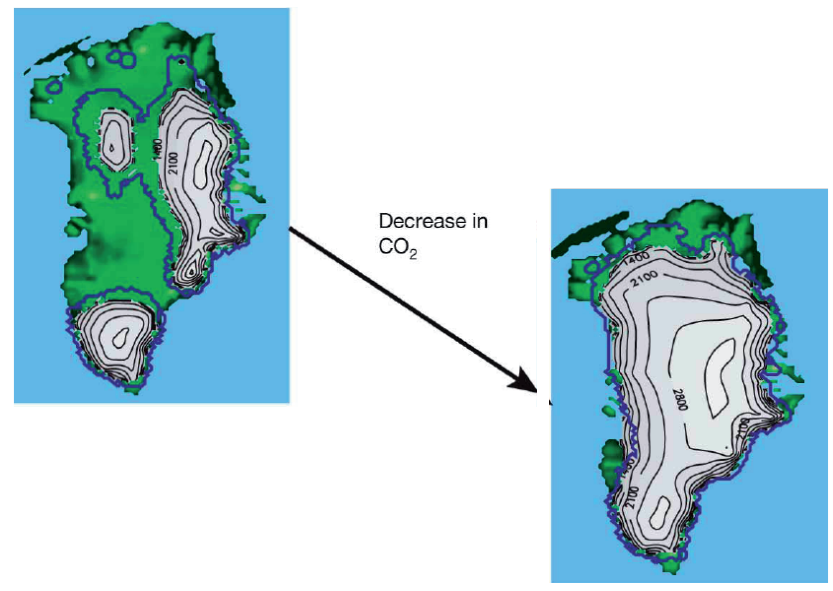

Fig. 5. Growth of Greenland ice sheet, induced by the decline in atmospheric $\mathrm{CO}_{2}$ from 400 to 280 ppmv (model of Lunt et al., 2008; modified).

have formed the mechanism suitable to induce the postulated but not yet identified major $\mathrm{CO}_{2}$ drop. For example, foraminiferal $\delta^{11} \mathrm{~B}$ and alkenone-based records (Foster et al., 2008; prelim. data presented as AGU poster) suggest various short-term and marked positive and negative shifts in mid-Pliocene $p \mathrm{CO}_{2}$. Apparently, they were coeval with the short-term re-openings and closings of CAS shown further below, but finally, around $2.75 \mathrm{Ma}$ ago, may have summed up to a long-term decline of 100-120 ppmv.

\section{Models and concepts on the final closure of the Pana- manian Isthmus and implications for global climate change}

The final closure of Central American Seaways (CAS) presents the most recent plate-tectonic change of ocean configuration in geological history, an uplift process resulting from the subduction of the Galapagos aseismic ridge (Meschede and Barckhausen, 2002). Weyl (1968) and thereafter Keigwin (1982) first proposed this event as the potential forcing for the onset of major NHG and Quaternary-style climates. On the basis of diverging nannofossil communities, Kameo and Sato (2000) first succeeded to pin down the final closure of CAS to an age close to $2.76 \mathrm{Ma}$ (marine isotope stage (MIS) G6; equal to $2.73 \mathrm{Ma}$ on the revised timescale LR04; Lisiecki and Raymo, 2005), a timing that indeed comes close to the onset of major NHG as first derived by Shackleton et al. (1984).

Maier-Reimer et al. (1990) first employed an ocean general circulation model (O-GCM) to simulate the potential impact of the closure of CAS on ocean circulation. Accordingly, the closure stopped the incursion of Pacific lowersalinity surface waters diluting West Atlantic surface water salinity (SSS), thus inducing a profound rise in poleward heat 

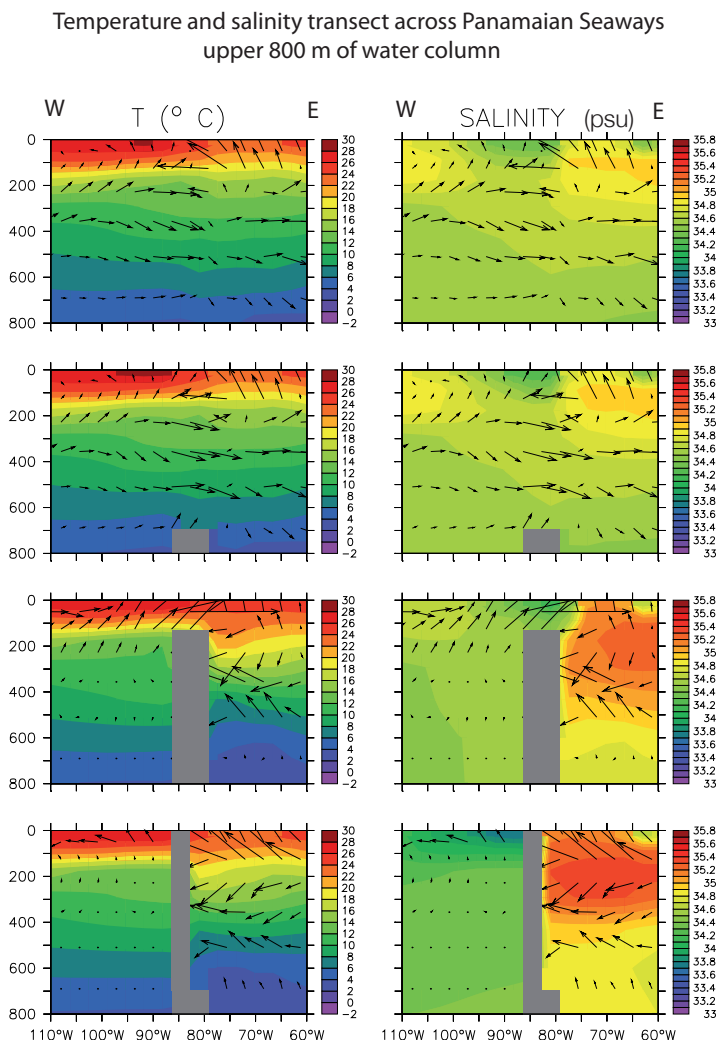
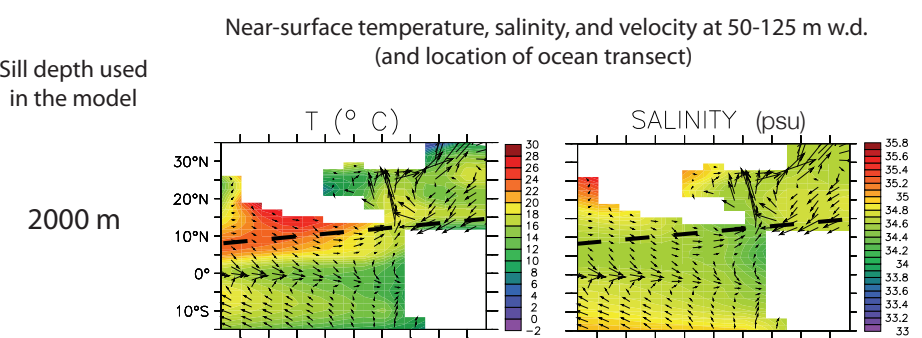

$700 \mathrm{~m}$
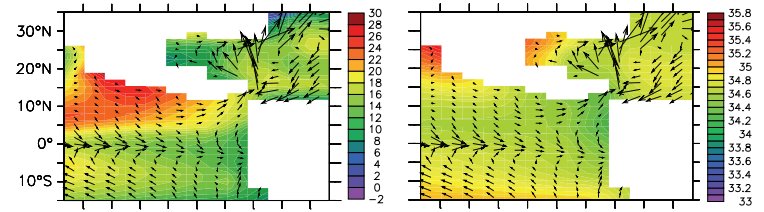

$130 \mathrm{~m}$
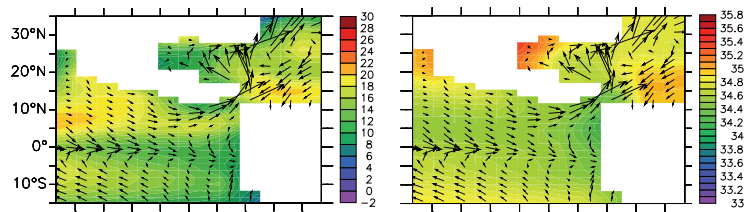

$0 \mathrm{~m}$

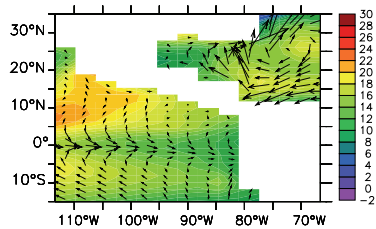

Fig. 6. Impact of shoaling of Panamanian Seaways on Caribbean and equatorial east Pacific upper ocean water mass signatures in a highdiffusion (HD) experiment with the UVic-ESCM model (Schneider and Schmittner; 2006).

and salt transport and in turn, in Atlantic MOC. Later-on, a number of more sophisticated GCM tests basically confirmed these results (e.g., Murdock et al., 1997; Mikolajewicz et al., 1997; Prange and Schulz, 2004; Klocker et al., 2005; Schneider and Schmittner, 2006; Lunt et al., 2007, 2008). Schneider and Schmittner (Fig. 6) focussed on testing the role of four subsequent Panamanian sill depths from -2000 up to zero $\mathrm{m}$ on adjacent sub-SSS and sea surface temperature (SST) distributions. Different from previous concepts (Haug et al., 2001), they found Pacific-to-Atlantic sub-SSS contrasts at $50-125 \mathrm{~m}$ water depth, which did not respond with any noteworthy rise to the closure of intermediate waters from 2000 to $700-500 \mathrm{~m}$ water depth. At sill depths of 300 to $250 \mathrm{~m}$ only one third, at $130 \mathrm{~m}$ sill depth, however, already two thirds of the final sub-SSS contrasts (i.e., 1.2 psu) were established (Figs. 6 and 7). Accordingly, it was only the closing of the last $250-130 \mathrm{~m}$ depth of the Panamanian gateways, that was finally crucial in triggering major changes in Atlantic MOC.

Driscoll and Haug (1998) first conceived the implications of an enhanced North Atlantic MOC for the onset of major NHG (Fig. 8). Their "Panama Hypothesis" tries to reconcile the effects of two actually counteracting forcings, increased poleward heat and moisture transports for the build-up of a continent-wide ice sheet on Greenland. Driscoll and Haug postulated that stronger heating of the northern North Atlantic will result (1) in enhanced evaporation and moisture transport via the westerlies to northwestern Eurasia, as also displayed by the model of Lunt et al. (2007), (2) in much increased river discharge from Siberia to the Arctic Ocean, in turn leading to (3) more sea ice formation and (4) more Arctic albedo, and therefore, to (5) more favorable conditions for the growth of Northern Hemisphere ice sheets.

On the basis of their fully coupled, fully dynamic oceanatmosphere models, Klocker et al. (2005) and later Lunt et al. (2007) indeed confirmed that the closure of Panamanian Seaways provided the warming expected for the North Atlantic (Fig. 9), more intense Atlantic thermohaline circulation, and enhanced precipitation over Greenland and the Northern Hemisphere continents. However, they found that these forcings may be too small by an order of magnitude to produce the observed major ice sheet growth which marked the onset of major NHG and Quaternary-style climates. Though we wonder, to which degree the HadCM3 global climate model is able to capture the full possible range of regional sea-ice variations in the Arctic and the corresponding changes in surface albedo. The model used in the study of Lunt et al. $(2007,2008)$ does not include a realistic 


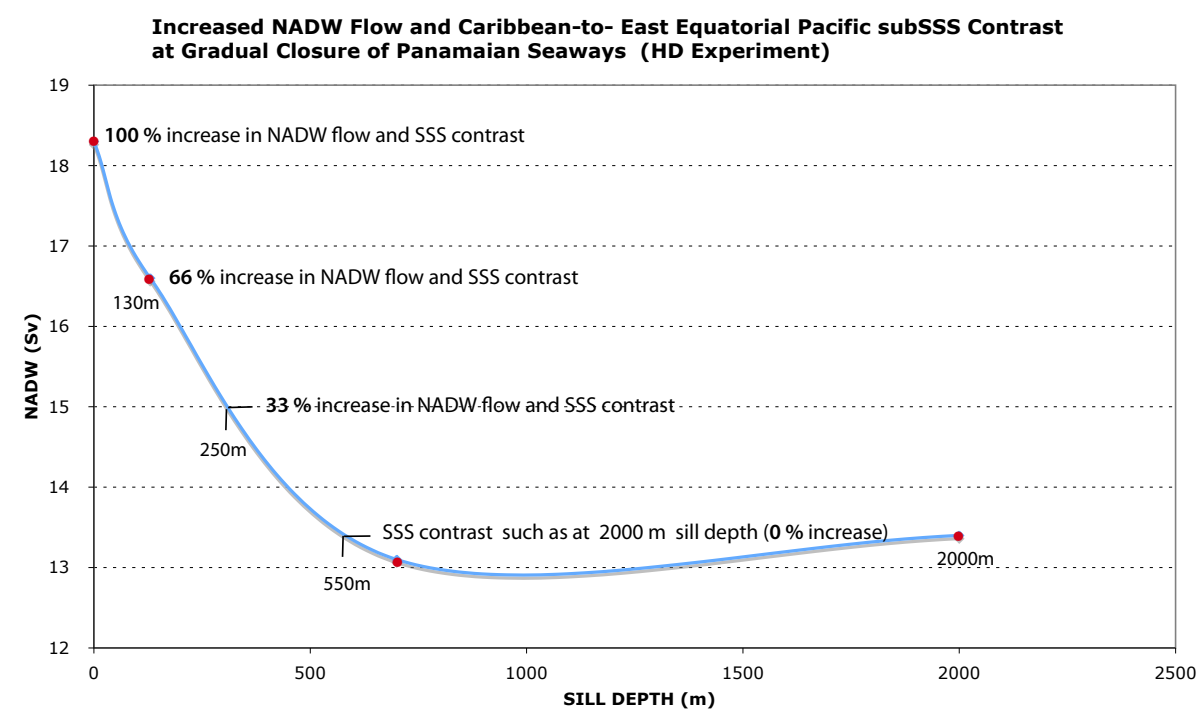

Fig. 7. Increase in NADW flow and underlying East-Pacific-to-Caribbean sub-sea surface salinity (subSSS) contrasts over the final closure of the Panamanian Seaways. Changes in NADW flow were calculated from HD model results of Schneider and Schmittner, 2006; changes in SSS anomaly at 50-125 m w.d. in waters ambient to Sites 999 and 1241 were estimated from Fig. 6 values and considered as forming a largely linear relationship with changes in NADW flow.

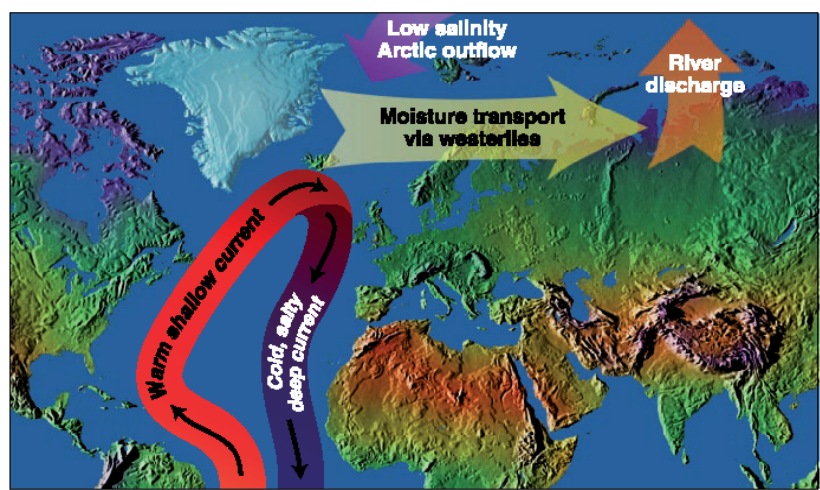

Fig. 8. Driscoll and Haug (1998) model on "Panama Hypothesis". As a result of closing CAS the poleward transport of heat with the North Atlantic Current is intensified, inducing enhanced evaporation in the North Atlantic and in turn, a rise of poleward atmospheric moisture transport and finally, a freshening of the Arctic Ocean, sea ice formation, and enhanced albedo.

sea-ice rheology (Bryan, 1969) and uses simplistic parameterizations for sea-ice albedo (Gordon et al., 2000). Therefore, climate feedbacks that involve changes in sea-ice cover and the associated surface albedo are subject to large uncertainties in these model simulations. Moreover, we note that ice albedo is commonly used as a tuning parameter in coupled climate models, which makes the models less reliable with respect to predictions of future or past Arctic sea-ice changes (Eisenman et al., 2007).

Recently, Molnar (2008) published harsh critiques on the proposed linkages between closing CAS and the onset of Quaternary-style Ice Age climates, arguments that need to be compared with the records presented below.

\section{Sediment records on the final closure of CAS}

In contrast to the view of Molnar (2008), most of the modelpredicted rise in SSS differences between the Caribbean and the eastern Equatorial Pacific forms a clear record of the closure of the Panama Seaways over the last $250-300 \mathrm{~m}$ water depth (Figs. 6, 7). A range of rising SSS differences closely similar to the modelled anomalies was obtained from calculating the anomaly record between millennial-scale midPliocene SSS records from Ocean Drilling Program (ODP) sites 999 and 1241 drilled to the northeast and southwest of the Panama Isthmus (Fig. 10; based on Groeneveld, 2005; Groeneveld et al., 2006; Steph et al., 2006; Tiedemann et al., 2007), two sites that were well selected for this study. As first discussed by Bartoli et al. (2005), these SSS differences remained close to zero until $\sim 4 \mathrm{Ma}$. First but still reversible events of rising SSS differences occurred near $3.75 \mathrm{Ma}$ and 3.5-3.3 Ma, then reaching up to $0.5 \mathrm{psu}$ and more; at $3.16 \mathrm{Ma}$ they first reached $0.8-1.0 \mathrm{psu}$. These short precursor events of a major shallowing and/or closure of the Panama seaways may in part record short-term volcano-tectonic events, in part orbital ice and sea level cycles. In contrast, largely irreversible SSS contrasts of $0.4-0.9$ and 1.0-1.3 psu were found after $2.95 \mathrm{Ma}$ and at $2.5 \mathrm{Ma}$, respectively, values that came close to the model-predicted maximum anomalies in SSS. The latter two events reflect the two-step final closure of the shelf seaway induced by the uplift of the Panama Isthmus, a forcing this time stronger than any ongoing overlapping orbital sea-level fluctuations also seen in the record of Fig. 10. Land-based evidence from Panama likewise documents the first full closure of the seaway near $2.85 \mathrm{Ma}$ (Coates et al., 2004 , and oral communication). 
(a) Surface temperature change, Closed Seaway - Open Seaway (K)

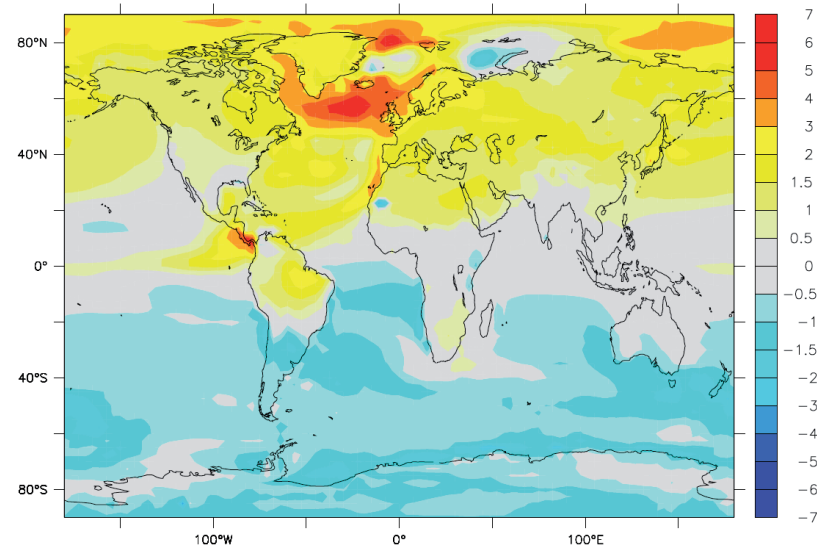

(b) Precipitation change, Closed Seaway - Open Seaway (mm/day)

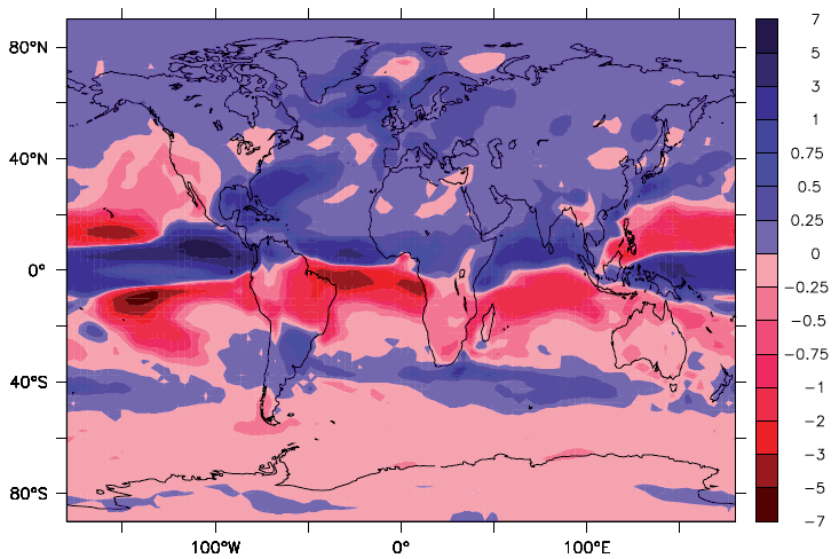

Fig. 9. Changes in surface temperatures (a) and precipitation (b), comparing Closed Panamanian Seaways with Open Seaways (model experiments of Lunt et al., 2007).

In terms of both millennial-scale age control and environmental evidence for the final closure of CAS, we regard the SSS anomaly record of Fig. 10 as clearly superior to the various early published low-resolution and, in part, poorly dated and discontinuous marine records and bioevolution-based evidence listed for constraining the closure of CAS by Molnar (2008). Last but not least, we see a great advantage of the Caribbean-to-East Pacific SSS anomaly record in its close resemblance to SSS trends suggested by the model results of Figs. 6 and 7. In contrast to Molnar's objections, we conclude that initially still reversible, however, after $2.95 \mathrm{Ma}$ irreversible steps in closing the CAS are well defined in terms of age by means of rising SSS differences between the S.W. Caribbean and eastern Equatorial Pacific (Fig. 10) and consistent with land-based evidence.

Model-based evidence suggests that the final closure of the CAS necessarily led to two counteracting climatic forcings with an opposed effect on high-latitude glaciation, similar to the opposed forcings on modern Greenland ice (Fig. 1). (a)
An increased poleward heat transport (Fig. 9a) implied enhanced glacial melt, whereas (b) an increased poleward transport of atmospheric moisture to northern Eurasia (Fig. 9b) induced a freshening of the Arctic ocean and enhanced snow and ice accumulation, in particular at perennial temperatures below zero centigrade. In the following, we display sediment records from the northern North Atlantic that provide independent evidence for the two opposed processes and their potential links to a coeval and/or slightly delayed onset of NHG.

\section{North Atlantic sediment records of the onset of major NHG}

The onset of major NHG is best documented at ODP Site 907 to the east of Greenland and the East Greenland and East Iceland Currents (Figs. 11-13), a position ideal in monitoring the discharge of ice rafted debris (IRD) of icebergs coming from northeast Greenland and the Arctic ocean. A second IRD record measured at Site 1307 (Fig. 11; Expedition 303 Scientists, 2006) also includes IRD originating from mountain glaciers calving nearby in southeast Greenland up to the extended Scoresby Sound. Accordingly, IRD changes at Site 907 (Jansen et al., 2000; Bartoli et al., 2005) may best display the long-term and major trends in the evolution of NHG, whereas IRD of Site 1307 near the southern tip of Greenland may add interesting aspects with regard to the East Greenland Current (EGC) and short-term orbital-scale climate oscillations.

IRD abundances at Site 907 (Fig. 12) already suggest some kind of causal link between the build-up of major NHG on northern Greenland and the final changes in CAS aperture, in harmony with the model of Driscoll and Haug (1998). The suite of changes in IRD 3.4-2.6 Ma follow with great detail and a persisting lag of $\sim 40 \mathrm{ky}$ a closely similar suite of distinct steps in the evolution of CAS (Fig. 12). For example, SSS contrasts between East Pacific and Caribbean document a first full closure at 3.24-3.16 Ma, a subsequent suite of three short re-openings and minor closings 3.13-2.97, and a final closure 2.96-2.87 Ma. Except for the final episode of CAS closure around $2.67 \mathrm{Ma}$ (when a major Greenland ice sheet was already established; see below), each of these events was followed directly by a distinct rise or drop in IRD abundance (on an exponential scale), and a final IRD extreme at MIS G10, 2.82 Ma. However, this match of two records does not yet provide the actual evidence necessary to infer the origin of major NHG (in harmony with doubts of Molnar, 2008). Certainly, the persistent lag of changes in IRD abundance demonstrates (1) significant memory effects in the climate system, and (2) that the oscillations in the build-up and melt of continental ice volume and resulting eustatic sea level variations cannot have controlled primarily the closing events of the CAS, but viceversa, that the CAS events have somehow controlled variations in IRD. 


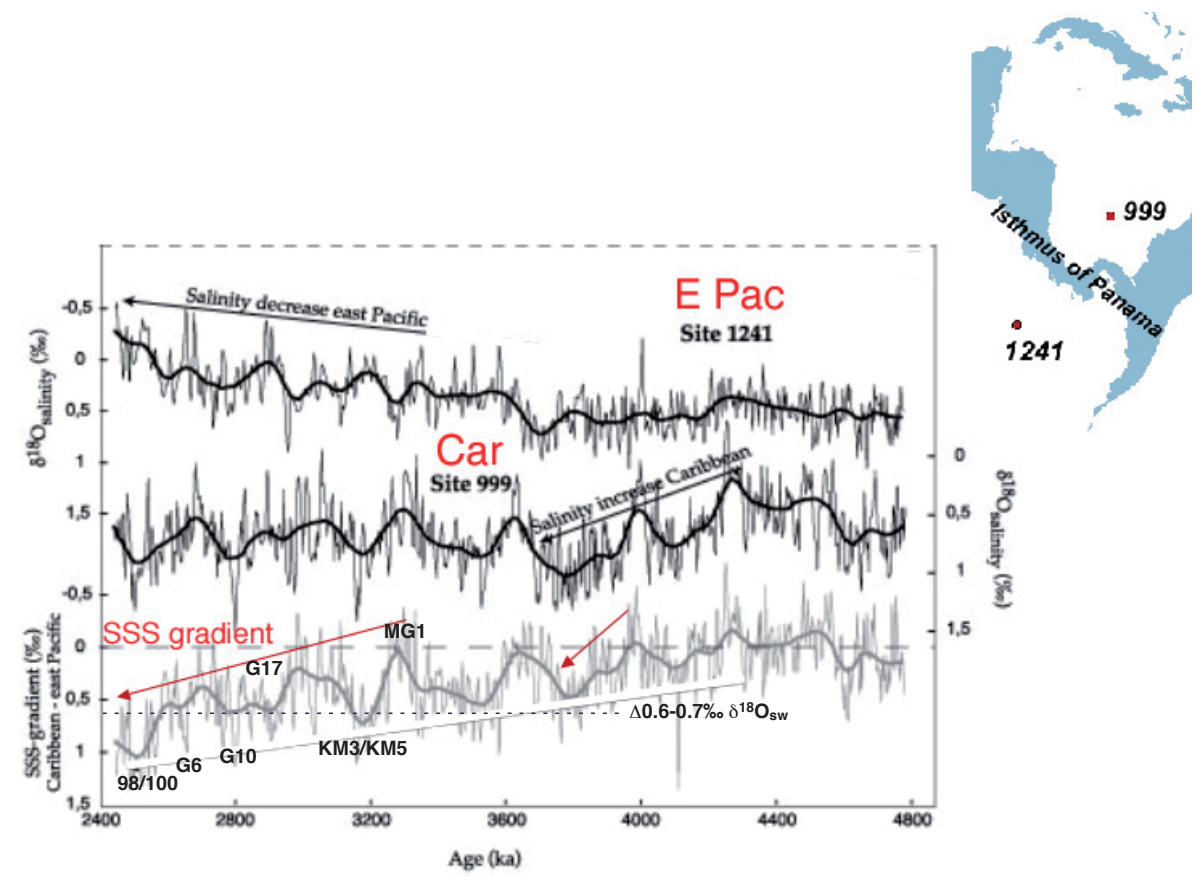

Fig. 10. Mid-Pliocene increase in SSS gradient between Caribbean (CAR) and eastern equatorial Pacific (E Pac), deduced from $\delta^{18} \mathrm{O}$ and $\mathrm{Mg} / \mathrm{Ca}$-based SST values of Globigerinoides sacculifer, a species growing at $\sim 50-100 \mathrm{~m}$ water depth (Groeneveld, 2005; Groeneveld et al., 2006; Steph et al., 2006). A $\delta^{18} \mathrm{O}_{\mathrm{w}}$ gradient of $0.6-0.7 \%$ (hatched line; uncertainty of $\sim 0.07 \%$ for the 10 -point running average of $\delta^{18} \mathrm{O}_{\mathrm{w}}$ ) equates to a SSS gradient of 1.2-1.8 psu (Simstich et al., 2002) which correspond to a full closure of CAS according to the gradients shown in Fig. 6. Age scales tuned to Tiedemann et al. (1994), slightly modified by Tiedemann et al. (2007), come close to LR04 (Lisiecki and Raymo, 2005). Small letters and numbers at SSS gradient record (98/100, G6, G10, etc.) label marine isotope stages.

The IRD record from IODP Site 1307 (Fig. 12a) appears less straightforward for correlations with the closings of CAS because of multiple potential IRD sources - and two competing age models (Fig. 13). Using age model 1, a first increase in IRD paralleled the first full closure of CAS around 3.2 Ma (MIS KM3-KM2), without any time lag. However, this increase continued later on from 3.17-3.02 Ma, in contrast to the coeval step-wise re-opening of CAS. Using age model 2, which appears slightly superior to model 1 (Fig. 13), IRD showed a medium-high IRD peak during the eminent glacial precursor stage M2, 3.33-3.24 Ma, but the main IRD increase only occurred from 3.11-3.02 Ma, that was $50 \mathrm{kyr}$ after the first closure and coeval with the re-opening of CAS. After a subsequent minor abundance drop, IRD formed a plateau at high level, starting with the major re-opening of CAS near 3.0 Ma and ending with a further major increase 2.7-2.66 Ma.

In summary, we need to consider significant memory effects linked to the build-up of continental ice volume, behavior of mountain glaciers, ice break-outs, and IRD formation at cold stages, effects controlled by overlapping consequences of ice isostasy, size of pre-existing ice sheets and fjords, supposed thermal isolation of Greenland, changing amplitudes of orbital cycles, etc. These effects are inbuilt into the complex climate system and imply significant lags for the IRD signal, that may amount to $>40 \mathrm{kyr}$, likewise during the long period of MIS MG7-MG11 (3.67$3.33 \mathrm{Ma}$ ), when CAS have been very shallow, and at MIS KM2 (3.13 Ma), right after the first full closure of CAS (Fig. 12a).

\section{Sediment records showing increased poleward heat transport and enhanced MOC in the North Atlantic}

After each major closing event of CAS we found evidence - with hardly any phase lag - for an increased poleward North Atlantic heat transport recorded at two different sediment profiles obtained from the eastern and central North Atlantic (Figs. 11 and 14; Bartoli et al., 2005). At both sites, lines enveloping short-term interglacial $(\mathrm{Mg} / \mathrm{Ca}$-based) SST maxima also display a distinct temperature rise by $2^{\circ}-$ $3^{\circ} \mathrm{C}$ coeval with or slightly lagging the major closing events of CAS near 3.33, 3.16, 2.92-2.8, and $2.66 \mathrm{Ma}$ (except for the poorly recovered MIS G4-G1 at Site 609). Vice versa, most subsequent drops in maximum temperature are linked to renewed openings of the seaways. Accordingly, midPliocene changes of poleward ocean heat transport linked to both the North Atlantic and Irminger Currents indeed appear closely related to the final closing and re-opening of CAS, as 


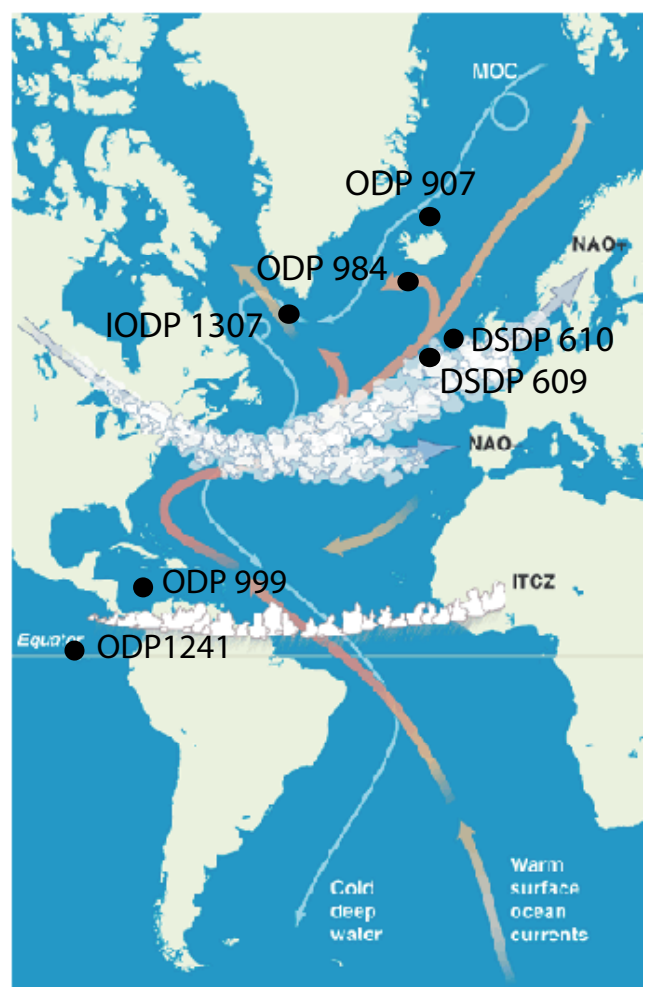

Fig. 11. DSDP, ODP, and IODP site locations and surface and deepwater currents in the Atlantic.

predicted by model simulations and in contrast to the doubts of Molnar (2008).

Each warming of the North Atlantic Current matched an increase in sea surface salinity by $0.2-0.4$ psu (as inferred from paired planktic $\delta^{18} \mathrm{O}$ and $\mathrm{Mg} / \mathrm{Ca}$-based SST values; Bartoli et al., 2005). Accordingly, each closing of CAS and, in particular, the major event 2.95-2.82 Ma resulted in significantly intensified convection of deepwater in the Nordic Seas. The result of stronger Atlantic overturning circulation is suggested by a long-term temperature drop $\left(-1.5^{\circ}\right.$ and $-2^{\circ} \mathrm{C}$ ), a slight salinity rise, and an increase in density (benthic $\delta^{18} \mathrm{O}$ values) of North Atlantic Deep Water at Sites 609 and 610 (Fig. 14). These trends paralleled clearly the major twofold (exponential) rise in IRD at Site 907, that depicts the onset of major Northern Hemisphere Glaciation and Quaternary-style climates, in particular, around 2.932.82 Ma, when high IRD contents started to persist. The coeval changes suggest a causal linkage between enhanced MOC and the build-up of continental ice sheets.

\section{Sediment records of increased poleward freshwater transport}

Model simulations (Lunt et al., 2007; Prange and Schulz, 2004; Schneider and Schmittner, 2006) suggest that the closure of Panamanian Seaways led to increased precipitation, in particular, over East Greenland, the northeastern North Atlantic, and western and central Europe (Fig. 9b), and fairly minor, all over the Northern Hemisphere. Today, the East Greenland Current (EGC) and its low sea surface salinity (SSS) of 32-33 psu and temperatures near $0^{\circ} \mathrm{C}$ provide a summary record of the outflow of low-saline surface waters from the Arctic Ocean into the northwestern North Atlantic. Thus IODP Site 1307 drilled near to the southern tip of Greenland (Fig. 11; Expedition 303 Scientists, 2006) occupies an ideal location for monitoring past changes in the EGC and its source region, the Arctic Ocean, including potential events of mid-Pliocene freshening and cooling to test the "Panama Hypothesis".

As soon as a full closure of Panamanian Seaways had been completed for the first time around 3.2-3.16 Ma (although then still reversible), the sediment record of Site 1307 indeed showed a significant change in the composition of EGC waters from 3.15/3.08-3.02 Ma with Age Model 2 and from 3.3/3.22-3.02 Ma with Age model 1 (Fig. 12b and c; SST/SSS records over Kaena subchron are irregular because of insufficient foraminiferal tests; Fig. 13). Both SST maxima and minima started to decrease by $6^{\circ} \mathrm{C}$ in parallel with SSS oscillations that dropped by $\sim 1 \%$ o $\delta^{18} \mathrm{O}_{\text {surface water equal }}$ to $\sim 2$ psu. This immense change in the density of subsurface waters (probable habitat of $N$. atlantica per analogy to $N$. pachyderma $s$; Simstich et al., 2002) exceeds by far any model predictions of enhanced poleward atmospheric moisture transport (Klocker et al., 2005; Lunt et al., 2007). The freshening of the EGC led necessarily to enhanced stratification of the northwestern North Atlantic and reduced stability of Atlantic MOC and introduced a new, "Quaternary"-style regime of the EGC, which was traced at Site 1307 at least until 2.7 Ma.

The great freshening of the EGC, in turn, is an immediate record of Arctic sea surface conditions, hence providing indirect but important evidence for a coeval substantial expansion of perennial sea ice and enhanced albedo in the Arctic Ocean, the condition crucial for promoting the onset of major NHG as result of the full closure of CAS. Our evidence appears in harmony with early diatom records (Herman, 1974; Stein, 2008) and opposed to various low-resolution records (Darby et al., 2008; Frank et al., 2008) that suggest a much earlier date for the onset of perennial sea ice in the Arctic Ocean.

Obviously the mid-Pliocene increase of poleward freshwater transport has overcompensated by far the coeval effect of enhanced poleward heat transport. However, the question, as to where the freshwater flow of the EGC has actually originated, remains unsolved. Although GCM models show that 

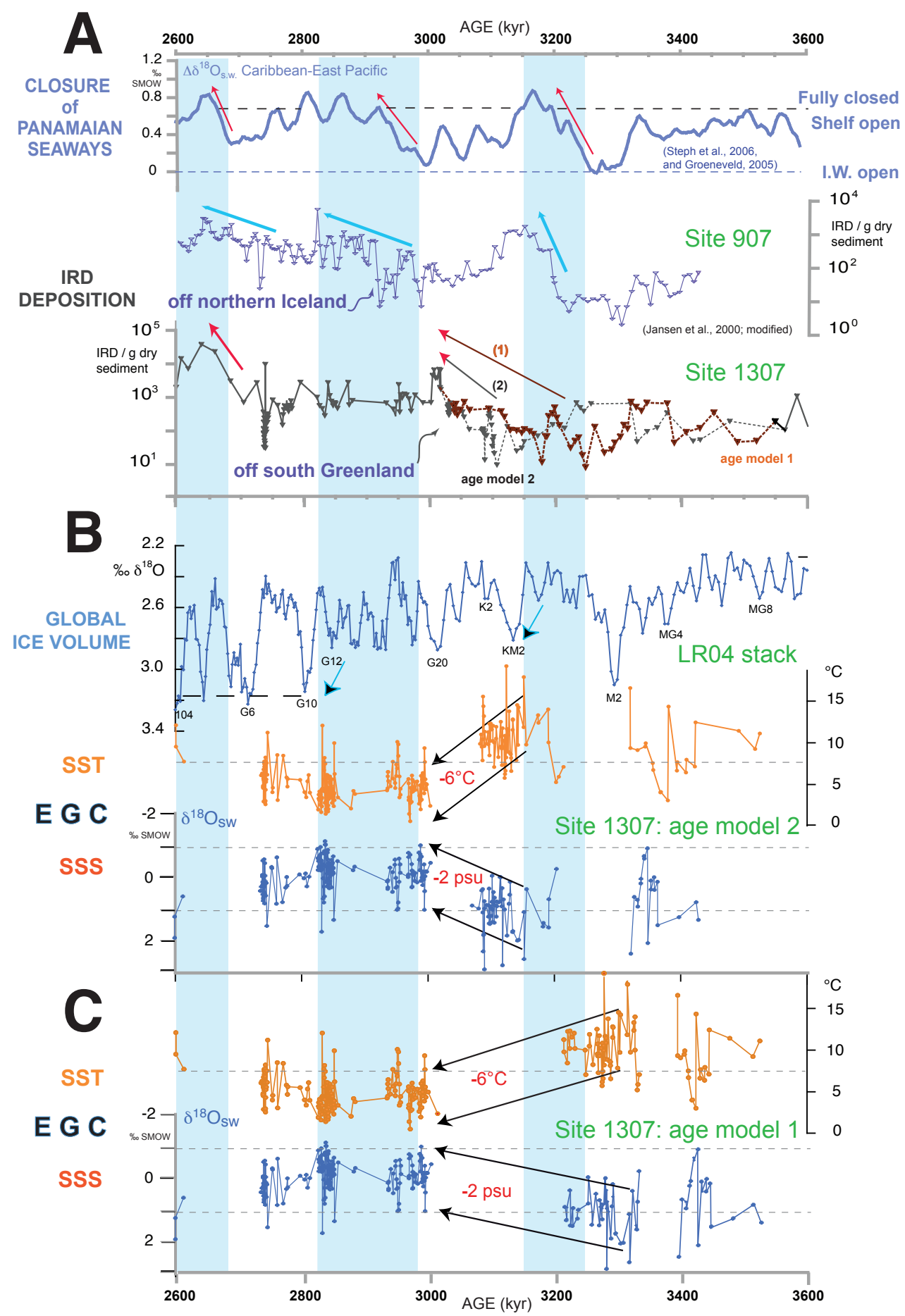

Fig. 12. (A) Closure of CAS (record inverted from Fig. 10) and IRD abundance at ODP Site 907 (Jansen et al., 2000; age model modified by Lacasse et al., 2002) and IODP Site 1307 (age models 2 and 1 are displayed in Fig. 13), where the great IRD increase 3.12/3.22$3.02 \mathrm{Ma}$ matches a major cooling and freshening of the East Greenland Current (EGC), shown below. (B) and (C) Stacked benthic $\delta^{18} \mathrm{O}$ record LR04 (Lisiecki and Raymo, 2005; small letters and numbers label marine isotope stages 104 - MG8) versus major sub-sea surface temperature (SST) and salinity (SSS) drops of the EGC at IODP Site 1307, 3.5-2.7 Ma, displayed for age models 2 and 1. Sub-SST estimates are based on the $\mathrm{Mg} / \mathrm{Ca}$ ratio of planktic subsurface species Neogloboquadrina atlantica. Two-psu shift in SSS is derived from a shift in $\delta^{18} \mathrm{O}_{\text {surface water }}\left(\delta^{18} \mathrm{O}_{\mathrm{sw}}\right.$, i.e., the $\delta^{18} \mathrm{O}_{\text {carbonate }}$ record of $N$. atlantica as depicted in Fig. 13, after correction for SST) using a conversion factor of 1:2 as for modern EGC water (Simstich et al., 2002). 


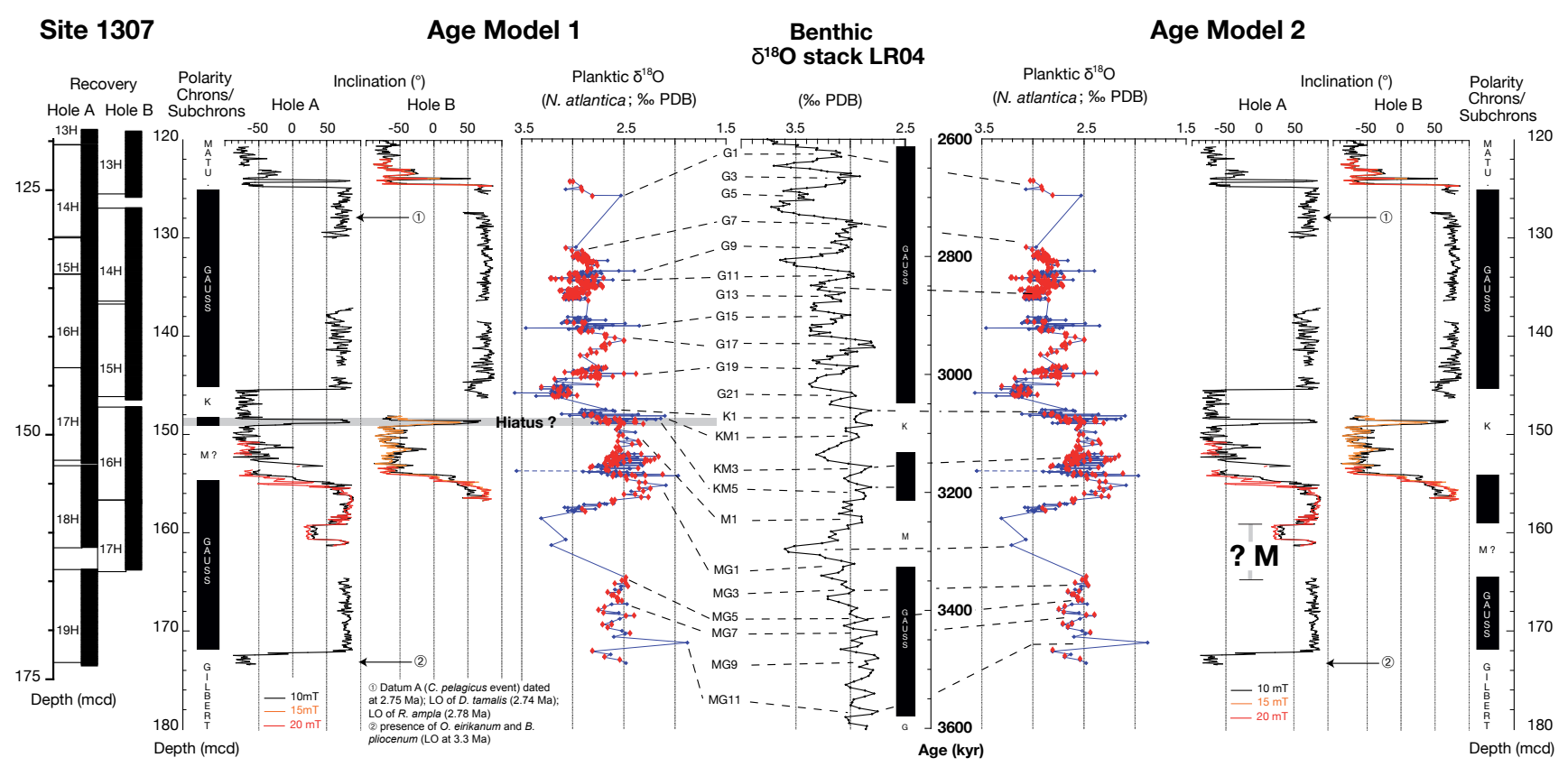

Fig. 13. Alternative mid-Pliocene age models 1 and 2 for IODP Site 1307. Far left: Site 1307 core recovery vs. depth. Left and far right margins: Magnetic polarity chrons and subchrons (Expedition 303 Scientists, 2006). Magnetic inclination obtained at 10, 15, and 20 milli Tesla. Note two different choices in assigning the Kaena (K) and Mammoth $(\mathrm{M})$ subchrons. MATU. = Matuyama chron. Figure center: Two different modes for tuning (thin hatched lines) the planktic $\delta^{18} \mathrm{O}$ record of Site 1307 to benthic $\delta^{18} \mathrm{O}$ stack LR04 (Lisiecki and Raymo, 2005); interglacial marine isotope stages are labeled. Red planktic $\delta^{18} \mathrm{O}$ values are measured on $>10$, blue values on $<10$ specimens. Potential hiatus in Age Model 1 is marked as grey bar. Biostratigraphic datums are numbered by (1) and (2).

the closure of CAS indeed implied a modest rise in poleward atmospheric moisture transport over vast parts of the northern Hemisphere (Fig. 9b) with a runoff into the Arctic Sea, this increase appears too modest for generating the major freshening found for the EGC and climatic changes such as the onset of major glacification on Greenland (Lunt et al., 2007, 2008).

Thus, we need a substantial further forcing to explain the striking SST/SSS decrease near MIS KM3 to G21. A recent model study (Steph et al., 2006) now suggests a suitable mechanism not yet considered (Fig. 15). Using the NCAR Community Climate System Model, version CCSM2/T31x3a (Prange, 2008), it shows that the full closing of CAS led to an increased steric height in the North Pacific ( $+15 \mathrm{~cm}$ as compared to the open CAS scenario), a decreased steric height in the North Atlantic $(-20 \mathrm{~cm})$ and, as a consequence, a doubling of the low-saline Arctic Throughflow ( $\sim 1$ Sv today) from the North Pacific through the Bering Strait up to a strongly intensified EGC, when assuming a Holocene sea level stand.

Unfortunately, no SST and SSS records have been established yet in the subarctic North Pacific for the interval 3.23.0 Ma. However, the global $\delta^{18} \mathrm{O}$ reference record LR04 (Fig. 2) indicates mid-Pliocene interglacial and in part, also cold-stage sea level stands (i.e., MIS M1-G17, except for MIS KM2 and G20) that were up to $30-40 \mathrm{~m}$ higher than today. Accordingly, the aperture of the Bering Strait near $\sim 3.15$ Ma may have been much wider and in turn, the increase in Bering Strait throughflow even larger. On the other hand, one may assume that the Bering Strait valley, today roughly $50 \mathrm{~m}$ deep, was gradually deepened by erosion with each emergence due to repetitive eustatic sea level lowerings which marked the 60 glacial stages of the last $3 \mathrm{~m} . \mathrm{y}$. In this case the model-based conclusion on a doubling of the throughflow appears more realistic. Possibly, the enhanced throughflow may be also reflected by increased advection of Pacific, in particular siliceous plankton.

Once low temperatures and low salinity of the EGC had been established, this current led to robust thermal isolation of East Greenland from the poleward heat transport further east through the North Atlantic and Norwegian Currents. Since this time the EGC formed a barrier important to promote the growth of continental ice. However, this feature is difficult to assess by any low-resolution climate models. Nevertheless, while almost the entire Northern Hemisphere becomes warmer in response to CAS closure, the simulations with CCSM2/T31x3a exhibit a year-round regional cooling over Central and South Greenland (up to $2^{\circ} \mathrm{C}$ ) along with enhanced annual snowfall (up to $50 \mathrm{~kg} / \mathrm{m}^{2}$ in South Greenland). Further details of these model results will be presented elsewhere (Prange and Schulz, 2009, in preparation). The Greenland continental ice sheet, once established, strengthened the 

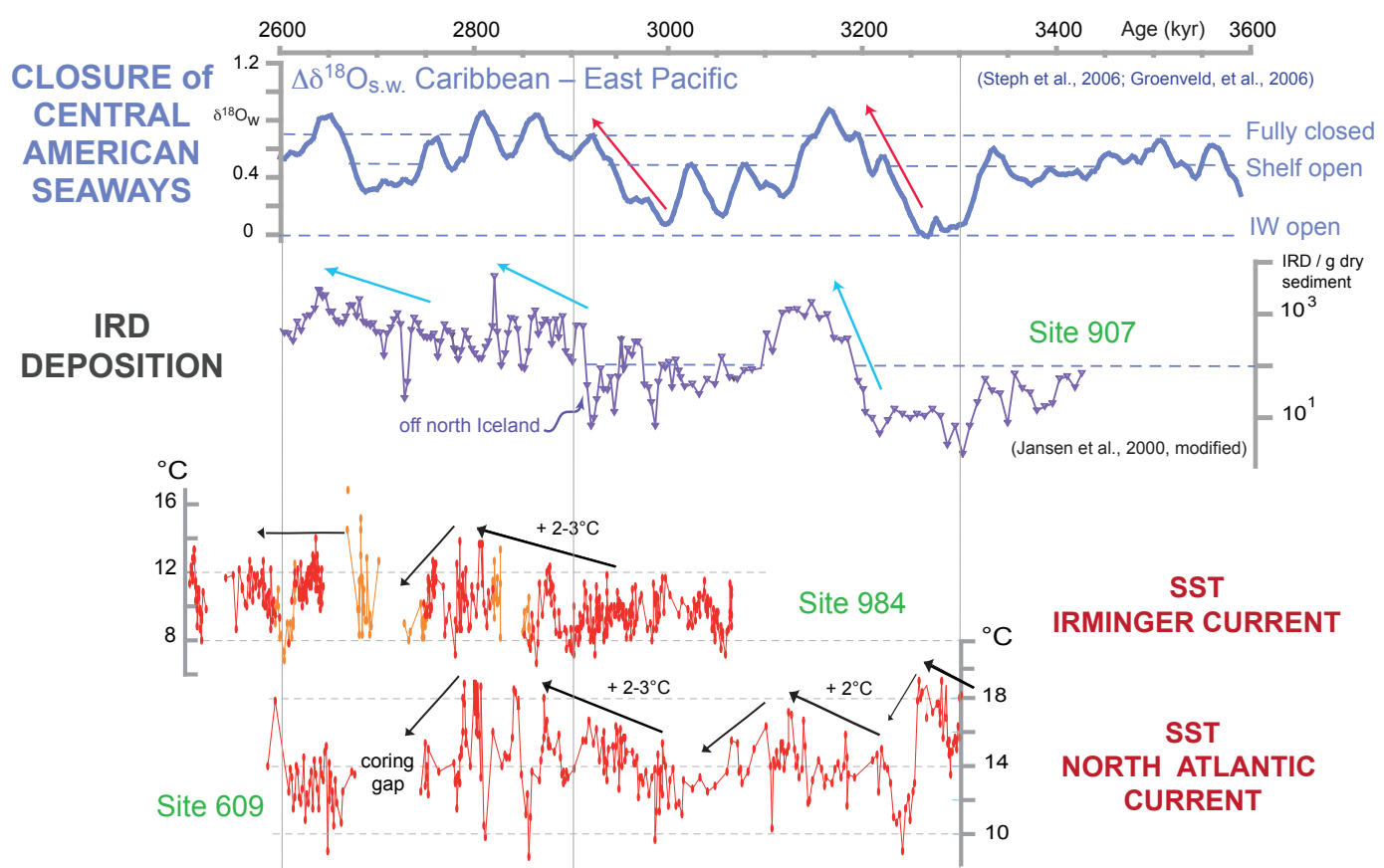

SST

IRMINGER CURRENT

SST

NORTH ATLANTIC

CURRENT

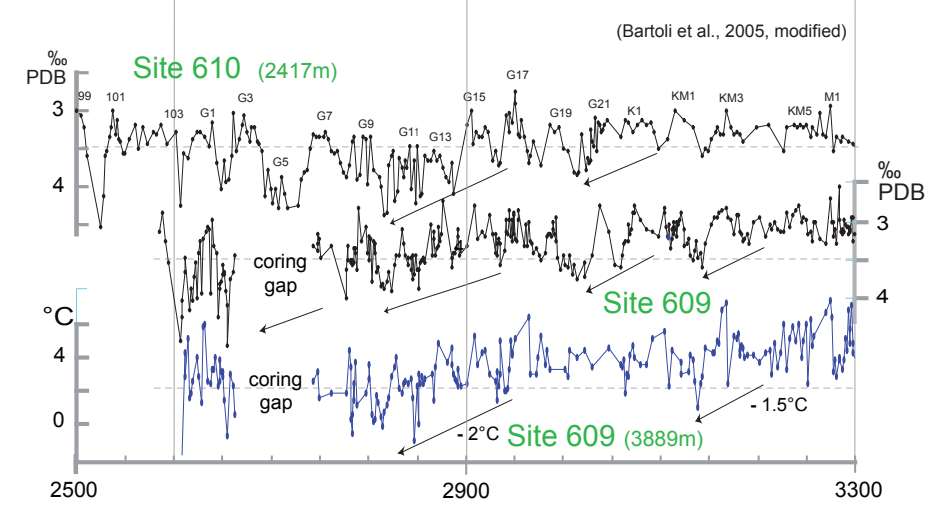

BENTHIC $\delta 180$

TEMPERATURES

Fig. 14. Closing of CAS (record inverted from Fig. 10), IRD abundance at Site 907, warming of northern North Atlantic (Mg/Ca-based SST records from ODP Sites 609 and 984), and increased Atlantic MOC deduced from a drop in $\mathrm{Mg} / \mathrm{Ca}$-based bottom water temperatures (BWT) at ODP Site 609 and increased benthic $\delta^{18} \mathrm{O}$ values at ODP Sites 609 and 610 (Bartoli et al., 2005, modified; Kleiven et al., 2002). Age scales tuned to Tiedemann et al. (1994). Small letters and numbers (101 - M1) label marine isotope stages (MIS).

Greenland High and, in particular, northerly winds along its eastern margin (cf. Toniazzo et al., 2004). In turn, the enhanced winds again strengthened the EGC flow. This positive feedback, a kind of long-term memory effect, may have been crucial in keeping the low-salinity and cold regime of the EGC going over interglacial stages K1, G21, and G19, when the CAS was shortly re-opened until the renewed and final closure after $2.95 \mathrm{Ma}$ (Fig. 12), when both effects (closed CAS and pronounced northerly winds along the East Greenland coast) were strong enough to drive a vigorous, similar to present-day, EGC that pushes the polar front across Site 1307.

In summary, we may conclude that the final linkage between the full closure of CAS and the onset of major NHG was accomplished through a significantly strengthened low- saline Bering Strait and Arctic Throughflow hitherto overseen (Molnar, 2008). The effects of this flow were far more substantial than the atmospheric poleward moisture transport and have clearly overcompensated the effects of enhanced poleward heat transport in the North Atlantic also resulting from the final closing of CAS. Once a major Greenland ice sheet had been established near 3.18-3.12 Ma and, in particular, after $2.9 \mathrm{Ma}$, it formed together with the outlined secondary feedback mechanisms, an ongoing nucleus for Quaternary-style climates recorded by Quaternary-style glaciations persisting in the Northern Hemisphere over the last 2.8-3.0 Ma.

Finally, it turns out that the outlined mid-Pliocene buildup of major NHG definitively does not form any analogue for a better understanding of the present and future evolution of 


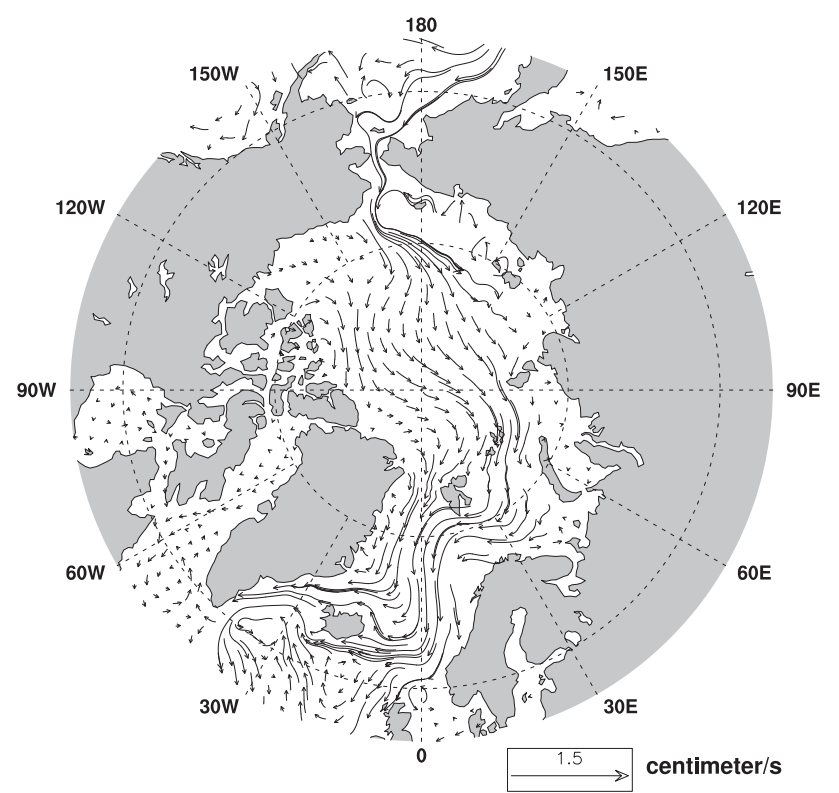

Fig. 15. Increased (doubled) flow rate of low-saline surface water through the Bering and Fram straits ("Arctic Throughflow") as a result of closing the CAS as simulated by the NCAR Community Climate System Model, version CCSM2/T31x3a (Prange, 2008). Shown here, is the difference between the two equilibrium runs (one with closed CAS, the other with open CAS arbitrarily applying a sill depth of $800 \mathrm{~m}$ and a width of $\sim 200 \mathrm{~km}$ ) in which the model is forced with present-day boundary conditions (i.e., a sensitivity study rather than a "true" simulation of Pliocene climates). The ocean component has a mean resolution of $3.6^{\circ} \times 1.6^{\circ}$ with $25 \mathrm{lev}-$ els, while the atmosphere has a resolution of $3.75^{\circ} \times 3.75^{\circ}$ with 26 levels (detailed description of experimental set-up in Steph et al., 2006).

the Greenland ice sheet as a result of "Global Warming" in the northern North Atlantic. Whereas the modern warming is induced by increased atmospheric $\mathrm{CO}_{2}$, that is particularly effective at high latitudes, the mid-Pliocene warming of the North Atlantic was linked to enhanced Atlantic MOC and the closing of equatorial seaways, forcings that were overcompensated by a significantly intensified cold Arctic Throughflow, in addition to the enhanced atmospheric poleward moisture transport. We have no reason to expect any analogue case of these ocean-driven changes in mid-Pliocene climate for the near future.

\section{Conclusions}

- Sediment records from the northern North Atlantic suggest that the final closing of Panamanian Seaways has led to the model-predicted increase in poleward heat transport and Atlantic MOC first near 3.25-3.15, lateron at 3.00-2.85 Ma.
- As result of the full closure of Panamanian Seaways the poleward flux of atmospheric moisture increased noteworthy and more important, a model study indicates that the flow of low-saline and cold surface waters from the North Pacific through the Bering Strait and Arctic Ocean was doubled. Together these two freshwater fluxes obviously have overcompensated the increased heat transport, thereby inducing a dramatic cooling and freshening of the EGC, a substantial expansion of perennial Arctic sea ice and albedo $\sim 3.2-$ 3.0 Ma, and in turn, the onset of major northern Hemisphere glaciation, first culminating near $2.82 \mathrm{Ma}$ (MIS G10).

- Cooling and freshening of the EGC probably involved a positive feedback, the thermal isolation of Greenland from increased poleward heat transport, thus further promoting a persistent glaciation of Greenland and NHG.

- The onset of NHG and the Quaternary is most likely no analogue for today: Increased atmospheric $p \mathrm{CO}_{2}$ is warming high latitudes in particular, thus leading to an enhanced melt of the ice on Greenland, whereas our results suggest that the mid-Pliocene formation of the full Greenland ice sheet was mainly induced by enhanced poleward freshwater transport and Arctic Throughflow, then compensating for a warming that mainly affected the temperate (Sites 609 and 610) and subpolar North Atlantic (Site 984).

Acknowledgements. We thank J. Groeneveld, P. Molnar, M. Schulz, S. Steph, R. Stein, and R. Tiedemann for fruitful discussions. Dan Lunt and a second anonymous reviewer for very helpful comments on a first version of the manuscript. Our studies are based on ample ODP and IODP sample materials analyzed with generous support by DFG Research Unit "Ocean Gateways" and project WE2679/2-1. The CCSM model experiments were performed on the IBM pSeries 690 Supercomputer of the Norddeutscher Verbund für Hoch- und Höchstleistungsrechnen (HLRN).

Edited by: G. M. Ganssen

\section{References}

Alley, R. B., Clark, P. U., Huybrechts, P., and Joughin, I.: Ice-sheet and sea-level changes, Science, 310, 456-460, 2005.

Bartoli, G., Sarnthein, M., and Weinelt, M.: Late Pliocene millennial-scale climate variability in the northern North Atlantic prior to and after the onset of Northern Hemisphere glaciation, Paleoceanogr., 21, PA4205, 1-15, 2006.

Bartoli, G., Sarnthein, M., Weinelt, M., Erlenkeuser, H., GarbeSchönberg, D., and Lea, D.: Final closure of Panama and the onset of northern hemisphere glaciation, Earth Planet. Sci. Lett., 237, 33-44, doi:10.1016/j.eps1.2005.06.020, 2005.

Bryan, K.: A numerical method for the study of the circulation of the world ocean, J. Comp. Physics, 4, 347-376, 1969. 
Cane, M. A. and Molnar, P.: Closing of the Indonesian seaway as precursor to east African aridification around 3-4 million years ago, Nature, 411, 157-162, 2001.

Coates, A. G., Collins, L. S., Aubry, M.-P., and Berggren, W. A.: The geology of the Darien, Panama, and the late Miocene-Pliocene collision of the Panama arc with northwestern South America, Geol. Soc. Amer. Bull., 116, 1327-1344, doi:10.1130/B25275.1, 2004.

Darby, D. A.: Arctic perennial ice cover over the last 14 million years, Paleoceanogr., 23, PA1S07, doi:10.1029/2007PA001479, 2008.

DeConto, R. M., Pollard, D., Wilson, P. A., Pälike, H., Lear, C. H., and Pagani, M.: Thresholds for Cenozoic bipolar glaciation, Nature, 455, 652-656, 2008.

Driscoll, N. W. and Haug, G. H.: A short circuit in thermohaline circulation: A cause for Northern Hemisphere Glaciation?, Science, 282, 436-438, 1998.

Eisenman, I., Untersteiner, N., and Wettlaufer, J. S.: On the reliability of simulated Arctic sea ice in global climate models, Geophys. Res. Lett., 34, L10501, doi:10.1029/2007GL029914, 2007.

Eldrett, J., Harding, I. C., Wilson, P. A., Butler, E., and Roberts, A. P.: Continental ice in Greenland during the Eocene and Oligocene, Nature, 446, 176-179, doi:10.1038/nature05591, 2007.

Expedition 303 Scientists, Site U1307, in: Proc. IODP, edited by: Channell, J. E. T., Kanamatsu, T., Sato, T., Stein, R., Alvarez Zarikian, C. A., Malone, M. J., and the Expedition 303/306 Scientists, 303/306, College Station TX (Integrated Ocean Drilling Program Management International, Inc.), doi:10.2204/iodp.proc.303306.107, 2006.

Foster, G. L., Seki, O., Schmidt, D. N., Kawamura, K., and Pancost, R.: Plio-Pleistocene $\mathrm{pCO}_{2}-\mathrm{a}$ multiproxy approach using alkenone and boron based carbonate system proxies, Eos Trans. AGU, 89(53), Fall Meet. Suppl. Abstract PP41D-1484, 2008.

Frank, M., Backman, J., Jacobsson, M., Moran, K., et al.: Beryllium isotopes in central Arctic Ocean sediments over the past 12.3 million years: Stratigraphic and paleoclimatic implications, Paleoceanogr., 23, PA1S02, doi:10.1029/2007/PA00147, 2008.

Gordon, C., Cooper, C., Senior, C. A., Banks, H., Gregory, J. M., Johns, T. C., Mitchell, J. F. B., and Wood, R. A.: The simulation of SST, sea ice extents and ocean heat transports in a version of the Hadley Centre coupled model without flux adjustments, Clim. Dynam., 16, 147-168, 2000.

Groeneveld, J.: Effect of the Pliocene closure of the Panamaian gateway on Caribbean and east Pacific sea surface temperatures and salinities by applying combined $\mathrm{Mg} / \mathrm{Ca}$ and $\delta^{18} \mathrm{O}$ measurements (5.6-2.2 Ma). PhD Thesis, University of Kiel, 2005.

Groeneveld, J., Steph, S., Tiedemann, R., Garbe-Schönberg, D., Nürnberg, D., and Sturm, A.: Pliocene mixed-layer oceanography for Site 1241 using combined $\mathrm{Mg} / \mathrm{Ca}$ and $\delta^{18} \mathrm{O}$ analyses of Globigerina sacculifer, in: Proc. ODP, Sci. Results, 202, edited by: Tiedemann, R., Mix, A. C., Richter, C., and Ruddiman, W. F., College Station, TX (Ocean Drilling Program), 1-27, doi:10.2973/odp.proc.sr.202.209. 2006.

Groeneveld, J., Nürnberg, D., Tiedemann, R., Reichart, G.J., Steph, S., Reuning, L., D. Crudeli, D., and Mason, P.: Foraminiferal $\mathrm{Mg} / \mathrm{Ca}$ increase in the Caribbean during the Pliocene: Western Atlantic Warm Pool formation, salinity influence, or diagenetic overprint?, Geochem. Geophys. Geosyst.,
9(1), Q01P23, doi:10.1029/2006GC001564, 2008.

Haug, G. H., Tiedemann, R., Zahn, R., and Ravelo, A. C.: Role of Panama uplift on oceanic freshwater balance, Geology, 29, 207210, 2001.

Huybers, P. and Molnar, P.: Tropical cooling and the onset of North American glaciation, Clim. Past, 3, 549-557, 2007, http://www.clim-past.net/3/549/2007/.

Hvidegaard, S. M. and Sandberg, L.: Study of elevation changes along a profile crossing the Greenland Ice Sheet, Poster EGU Vienna, EGU2009-8790, 2009.

Huybrechts, P., Gregory, J., Janssens, I., and Wild, M.: Modelling Antarctic and Greenland volume changes during the 20th and 21 st centuries forced by GCM time slice integrations, Global Planet. Change, 42, 83-105, 2004.

Jansen, E., Fronval, T., Ranck, F., and Channell, J. E. T.: PliocenePleistocene ice rafting history and cyclicity in the Nordic Seas during the last 3.5 Myr, Paleoceanogr., 15, 709-721, 2000.

Kameo, K. and Sato, T.: Biogeography of Neogene calcareous nannofossils in the Caribbean and the eastern equatorial Pacific floral response to the emergence of the Isthmus of Panama, Mar. Micropal., 39, 201-218, 2000.

Kawamura, K., Parrenin, F., Lisiecki, L., Uemura, R., Vimeux, F., Severinghaus, J. P., Hutterli, M. A., et al.: Northern Hemisphere forcing of climatic cycles in Antarctica over the past 360,000 years, Nature, 448, 912-927, 2007.

Keigwin, L. D.: Isotopic paleoceanography of the Caribbean and East Pacific: Role of Panama uplift in Late Neogene time, Science, 217, 350-353, 1982.

Kleiven, H. F., Jansen, E., Fronval, T., and Smith, T. M.: Intensification of Northern Hemisphere glaciations in the circum Atlantic region (3.5-2.4 Ma), Paleogeogr. Paleoclimatol. Paleoecol., 184, 213-223, 2002.

Klocker, A., Prange, M., and Schulz, M.: Testing the influence of the Central American Seaway on orbitally forced northern hemisphere glaciation: Geophys. Res. Lett., 32, L03703, doi:10.1029/2004GL021564, 2005.

Kürschner, W. M., Van der Burgh, J., Visscher, H., and Dilcher, D. L.: Oak leaves as biosensors of late Neogene and early Pleistocene paleoatmospheric $\mathrm{CO}_{2}$ concentrations, Mar. Micropal., 27, 299-312, 1996.

Lacasse, C. and van den Bogaard, P.: Enhanced airborne dispersal of silicic tephras during the onset of Northern Hemisphere glaciations, from 6 to 0 Ma records of explosive volcanism and climate change in the subpolar North Atlantic, Geology, 30, 623-626, 2002.

Laskar, J., Robutel, P., Joutel, F., Gastineau, M., Correia, A. C. M., and Levrard, B.: A long-term numerical solution for the insolation quantities of the Earth, Astronomy and Astrophysics manuscript no. La'2004, 1-26, 2004.

Lawrence, K., Liu, Z., and Herbert, T.: Evolution of the eastern tropical Pacific through Plio-Pleistocene glaciations, Science, 312, 79-83, 2006.

Lisiecki, L. E., and Raymo, M. E.: A Pliocene-Pleistocene stack of 57 globally distributed benthic $\delta^{18} \mathrm{O}$ records, Paleoceanogr., 20, PA1003, doi:10.1029/2004PA001071, 2005.

Lunt, D. J., Foster, G. L., Haywood, A. M., and Stone, E. J.: Late Pliocene Greenland glaciation controlled by a decline in atmospheric $\mathrm{CO}_{2}$ levels, Nature, 454, 1102-1105, 2008.

Lunt, D. J., Valdes, P. J., Haywood, A. M., and Rutt, I. C.: Clo- 
sure of the Panama Seaway during the Pliocene: implications for climate and Northern Hemisphere glaciation, Clim. Dynam., 30, 1-18, doi:10.1007/s00382-0070265-6, 2007.

Maier-Reimer, E., Mikolajewicz, U., and Crowley, T.: Ocean general circulation model sensitivity experiment with an open Central American Isthmus, Paleoceanogr., 5, 349-366, 1990.

Maslin, M. A., Haug, G., Sarnthein, M., Tiedemann, R., Erlenkeuser, H., and Stax, R.: Northwest Pacific Site 882: The initiation of Northern Hemisphere Glaciation, Sci. Res. ODP Leg, 145, 315-332, 1995.

Maslin, M., Haug, G., Sarnthein, M., and Tiedemann, R.: The progressive intensification of Northern Hemisphere glaciation as seen from the North Pacific, ICES-Geol. Rdsch. 85, 452-465, 1996.

Meschede, M. and Barckhausen, U.: Twin hotspot tracks and ridge jumps: the evolution of the Cocos Nazca Spreading Center, in: ODP's Greatest Hits, edited by: White, K. and Urquhart, E., Vol. 2, 1 pp., available from: http://www.oceandrilling.org/greatest_ hits2/PDFs/meschedehotspot.pdf, 2002.

Molnar, P.: Closing of the Central American Seaway and the Ice Age: A critical review, Paleoceanogr., 23, PA2201, doi:10.1029/2007PA001574, 2008.

Murdock, T. Q., Weaver, A. J., and Fanning, A. F.: Paleoclimatic response of the closing of the Isthmus of Panama in a coupled ocean-atmosphere model, Geophys. Res. Lett., 24, 253256, 1997.

Pagani, M., Zachos, J. C., Freeman, K. H., Tipple, B., and Bohaty, B.: Marked decline in atmospheric carbon dioxide concentrations during the Paleogene, Science, 309, 600-603, 2005.

Prange, M.: The low-resolution CCSM2 revisited: new adjustments and a present-day control run, Ocean Sci., 4, 151-181, 2008, http://www.ocean-sci.net/4/151/2008/.

Ravelo, A. C., Dekens, P. S., and McCarthy, M.: Evidence for El Nino-like conditions during the Pliocene, GSA Today, 16(3), 411, 2006.

Raymo, M. E., Grant, B., Horowitz, M., and Rau, G. H.: MidPliocene warmth: stronger greenhouse and stronger conveyor, Mar. Micropaleont., 27, 313-326, 1996.

Schneider, B. and Schmittner, A.: Simulating the impact of the Panamanian seaway closure on ocean circulation, marine productivity and nutrient cycling, Earth Planet. Sci. Lett., 246, 367380, doi:10.1016/j.eps1.2006.04.028, 2006.
Shackleton, N. J., Backman, J., Zimmerman, H., et al.: Oxygen isotope calibration of the onset of ice-rafting and history of glaciation in the North Atlantic region, Nature, 307, 620-623, 1984.

Simstich, J., Sarnthein, M., and Erlenkeuser, H.: Paired $\delta^{18} \mathrm{O}$ signals of $N$. pachyderma (s) and T. quinqueloba show thermal stratification structure in the Nordic Seas, Mar. Micropal., 48, 107125, 2002.

Steph, S., Tiedemann, R., Prange, M., Groeneveld, J., Nürnberg, D., Reuning, L., Schulz, M., and Haug, G.: Changes in Caribbean surface hydrography during the Pliocene shoaling of the Central American Seaway, Paleoceanogr., 21, PA4221, doi:10.1029/2004PA001092, 2006.

Stein, R.: Arctic Ocean Sediments - Processes, Proxies, and Paleoenvironment, in: Developments in Marine Geology, vol. 2, Elsevier, 1-592, 2008.

Tiedemann, R., Sarnthein, M., and Shackleton, N. J.: Astronomic timescale for the Pliocene Atlantic $\delta^{18} \mathrm{O}$ and dust flux records of ODP Site 659, Paleoceanogr., 9, 619-638, 1994.

Tiedemann, R., Sturm, A., Steph, S., Lund, S. P., and Stoner, J. S.: Astronomicaslly calibrated timescales from 6 to 2.5 Ma and benthic isotope stratigraphies, Sites 1236, 1237, 1239, and 1241, in: Proc. ODP, Sci. Results, 202, edited by: Tiedemann, R., Mix, A. C., Richter, C., and Ruddiman, W. F., College Station, TX (Ocean Drilling Program), 1-69, doi:10.2973/odp.proc.sr.202.210.2007, 2007.

Toniazzo, T., Gregory, J. M., and Huybrechts, P.: Climatic impact of a Greenland deglaciation and Its possible irreversibility, J. Climate, 17, 21-33, 2005.

Wang, P. X., Tian, J., Cheng, X. R., et al.: Major Pleistocene stages in a carbon perspective: The South China Sea record and its comparison, Paleoceanogr., 19, PA4005, doi:10.1029/2003PA000991, 2004.

Wang, P. X.: Global monsoon in a geological perspective, Chinese Science Bulletin, 54(7), 1113-1136, 2009.

Weyl, P. K.: The role of the oceans in climate change; a theory of the ice ages, Meteorol. Monogr., 8, 37-62, 1968.

Zachos, J., Pagani, M., Sloan,L., and Thomas, E.: Trends, rhythms, and aberrations in global climate 65 Ma to present, Science, 292, 686-693, 2001.

Zachos, J., Dickens, G. R., and Zeebe, R. E.: An early Cenozoic perspective on greenhouse warming and carbon-cycle dynamics, Nature, 451, 279-283, 2008. 